Article

\title{
Ganoderma lucidum Ethanol Extracts Enhance Re-Epithelialization and Prevent Keratinocytes from Free-Radical Injury
}

\author{
Mario Abate ${ }^{1,+}$, Giacomo Pepe ${ }^{2,+}$, Rosario Randino ${ }^{1,2}$, Simona Pisanti ${ }^{1}$ (D, \\ Manuela Giovanna Basilicata ${ }^{2}$, Verdiana Covelli ${ }^{2}$, Maurizio Bifulco ${ }^{3}$, Walter Cabri ${ }^{4}$ (D), \\ Anna Maria D’Ursi ${ }^{2}$, Pietro Campiglia ${ }^{2} \mathbb{D}$ and Manuela Rodriquez ${ }^{2, *}$ \\ 1 Department of Medicine, Surgery and Dentistry “Scuola Medica Salernitana”, University of Salerno, \\ Via Salvatore Allende, 84081 Baronissi Salerno, Italy; mabate@unisa.it (M.A.); rrandino@unisa.it (R.R.); \\ spisanti@unisa.it (S.P.) \\ 2 Department of Pharmacy, University of Salerno, Via Giovanni Paolo II, Fisciano, 84084 Salerno, Italy; \\ gipepe@unisa.it (G.P.); mbasilicata@unisa.it (M.G.B.); vcovelli@unisa.it (V.C.); dursi@unisa.it (A.M.D.); \\ pcampiglia@unisa.it (P.C.) \\ 3 Department of Molecular Medicine and Medical Biotechnologies, University of Naples Federico II, \\ Via Pansini, 80131 Naples, Italy; maurizio.bifulco@unina.it \\ 4 Chemistry Department "G. Ciamician”, University of Bologna, Via Selmi 2, 33, 40126 Bologna, Italy; \\ walter.cabri@unibo.it \\ * Correspondence: mrodriquez@unisa.it; Tel.: +39-089-969254; Fax: +39-089-969602 \\ $\dagger$ These two authors contributed equally to this work.
}

Received: 8 August 2020; Accepted: 26 August 2020; Published: 29 August 2020

\begin{abstract}
Ganoderma lucidum or Reishi is recognized as the most potent adaptogen present in nature, and its anti-inflammatory, antioxidant, immunomodulatory and anticancer activities are well known. Moreover, lately, there has been an increasing interest from pharmaceutical companies in antiaging G. lucidum-extract-based formulations. Nevertheless, the pharmacological mechanisms of such adaptogenic and regenerative actions remain unclear. The present investigation aimed to explore its molecular and cellular effects in vitro in epidermal keratinocyte cultures by applying liquid chromatography coupled to ion trap time-of-flight mass spectrometry (LCMS-IT-TOF) for analysis of ethanol extracts using ganoderic acid-A as a reference compound. The G. lucidum extract showed a keratinocyte proliferation induction accompanied by an increase of cyclic kinase protein expressions, such as CDK2 and CDK6. Furthermore, a noteworthy migration rate increase and activation of tissue remodelling factors, such as matrix metalloproteinases 2 and 9 (MMP-2 and MMP-9), were observed. Finally, the extract showed an antioxidant effect, protecting from $\mathrm{H}_{2} \mathrm{O}_{2}$-induced cytotoxicity; preventing activation of AKT (protein kinase B), ERK (extracellular signal-regulated kinase), p53 and p21; and reducing the number of apoptotic cells. Our study paves the path for elucidating pharmacological properties of G. lucidum and its potential development as cosmeceutical skin products, providing the first evidence of its capability to accelerate the healing processes enhancing re-epithelialization and to protect cells from free-radical action.
\end{abstract}

Keywords: Ganoderma lucidum; wound healing; triterpenic acids; oxidative stress; cosmeceuticals

\section{Introduction}

Ganoderma lucidum (Ling Zhi (in China) or Reishi (in Japan)), also known as "the fungus of immortality", is recognized among most important traditional medicinal mushrooms and most powerful adaptogens present in nature, since it acts as a regulator of biological functions [1-3]. 
The pharmacological properties of G. lucidum, such as anti-inflammatory, antioxidant, antiaging, immunomodulatory and antitumour activities [4-7], are due to its peculiar chemical composition in bioactive compounds such as polysaccharides, terpenoids, nucleotides, steroids, fatty acids, proteins and glycopeptides [8,9]. Based on that, G. lucidum was also reported to act as an adjuvant in the treatment of several diseases, i.e., anorexia, hypertension, insomnia and chronic hepatitis [10-12].

Among the terpenoid class, the most represented are triterpenes (ganoderic acids, ganoderoli acids, ganoderenics and lucid acids), which exhibit well-recognized anti-inflammatory, antioxidant, antitumour, anti-hepatitis, hypoglycaemic, antimalarial and antimicrobial activities [13-19].

Recently, bioactive extracts of G. lucidum have been having great success in the nutraceutical and cosmeceutical fields; indeed, its triterpenic acids are often found in cosmetics formulations [20]. In this respect, the G. lucidum extracts can be used to control hyperpigmentation as photoprotective agents, to suppress inflammatory skin diseases, to mitigate lipid metabolic disorders and to balance gut microbiota composition [21-23]. Nevertheless, the mechanism of action and the biological targets behind their beneficial dermatological effects are still unclear. Thus, a deeper understanding of the biology of the molecular interactions might be acquired.

Therefore, in this work, we aimed first to assess the chemical composition of triterpenic acids in the fruiting body of the fungus, highlighting its potential as a valuable source of bioactive compounds, and then to provide any further pharmacological evidence of how the ethanol extract of G. lucidum is able to boost the wound healing process and to prevent premature skin aging, lessening free-radical action. These findings paved the path for developing highly effective G. lucidum-based cosmeceuticals.

\section{Results}

\subsection{Extraction and Characterization of G. lucidum Pericarp}

In the attempt to maximize ganoderic acid extraction, we performed an ethanol procedure operation as described in the Materials and Methods section. The ethanol extracts of G. lucidum were analysed by UHPLC-ESI-IT-TOF (Ultra-High Performance Liquid Chromatography-Electrospray ionization-Ion Trap-Time of flight) for quantification of triterpenes in G. lucidum ethanol extracts. In Figure 1, we showed the chromatographic profile acquired by UHPLC couplet to Photodiode Array Detector (PDA) $(\lambda=254 \mathrm{~nm})$ of the G. lucidum extract.

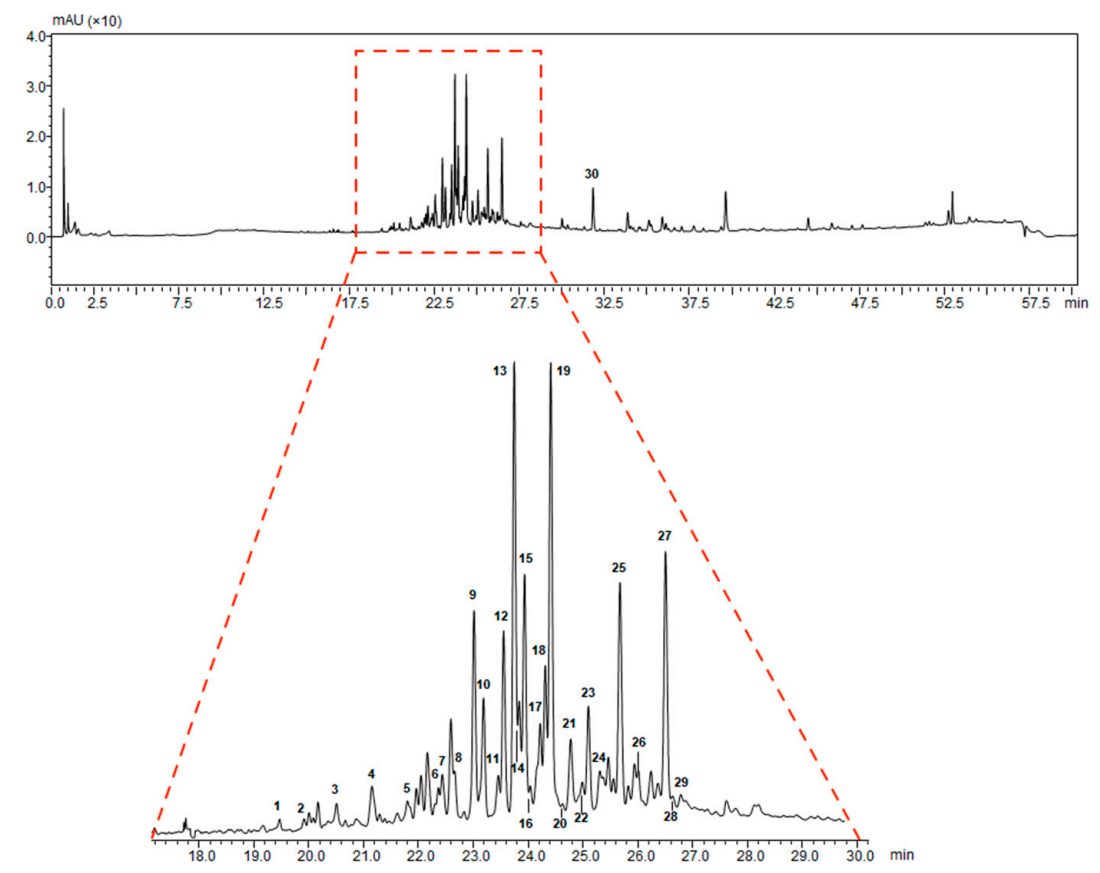

Figure 1. UHPLC-PDA $(\lambda=254 \mathrm{~nm})$ chromatographic profile of the G. lucidum extract. 
In Table 1, we showed the chemical structures of the identified triterpenoids. In Table 2, identification and quantification of triterpenes in the G. lucidum ethanol extract were reported.

Table 1. Chemical structures of the triterpenoids identified in the G. lucidum extract.

\begin{tabular}{|c|c|c|c|c|c|c|c|}
\hline Peak & $\begin{array}{c}\text { Retention } \\
\text { Time (min) }\end{array}$ & $\begin{array}{c}\text { Molecular } \\
\text { Formula }\end{array}$ & $\begin{array}{l}{[\mathrm{M}-\mathrm{H}]^{-}} \\
\text {Observed }\end{array}$ & $\begin{array}{l}\mathrm{M}-\mathrm{H}]^{-} \\
\text {Calculated }\end{array}$ & $\begin{array}{l}\text { Error } \\
(\mathrm{ppm})\end{array}$ & $\mathbf{M S}^{2} m / z$ & $\begin{array}{c}\text { Tentative } \\
\text { Identification }\end{array}$ \\
\hline 1 & 19.49 & $\mathrm{C}_{30} \mathrm{H}_{46} \mathrm{O}_{8}$ & 533.3106 & 533.3120 & -2.63 & 515.3096 & $\begin{array}{c}\text { 12-hydroxyganoderic } \\
\text { acid } C_{2}\end{array}$ \\
\hline 2 & 19.94 & $\mathrm{C}_{30} \mathrm{H}_{42} \mathrm{O}_{8}$ & 529.2807 & 529.2807 & 0.00 & 511.2468 & $\begin{array}{c}\text { 20-hydroxyganoderic } \\
\text { acid AM1 }\end{array}$ \\
\hline 3 & 20.55 & $\mathrm{C}_{30} \mathrm{H}_{42} \mathrm{O}_{8}$ & 529.2843 & 529.2807 & 4.89 & 511.2698 & $\begin{array}{c}\text { 12-deacetylganoderic } \\
\text { acid H }\end{array}$ \\
\hline 4 & 21.19 & $\mathrm{C}_{30} \mathrm{H}_{44} \mathrm{O}_{8}$ & 531.2962 & 531.2963 & -0.19 & 513.2930 & Ganoderic acid $\eta$ \\
\hline 5 & 21.75 & $\mathrm{C}_{30} \mathrm{H}_{42} \mathrm{O}_{8}$ & 529.2774 & 529.2807 & -6.23 & $\begin{array}{l}511.2707 ; \\
467.2884\end{array}$ & $\begin{array}{c}\text { 12-hydroxyganoderic } \\
\text { acid D }\end{array}$ \\
\hline 6 & 22.42 & $\mathrm{C}_{30} \mathrm{H}_{46} \mathrm{O}_{7}$ & 517.3189 & 517.3171 & 3.48 & 499.3131 & Ganoderic acid $C_{2}$ \\
\hline 7 & 22.49 & $\mathrm{C}_{30} \mathrm{H}_{46} \mathrm{O}_{8}$ & 529.2801 & 529.2807 & -1.13 & $\begin{array}{l}511.2640 \\
467.2661\end{array}$ & Ganoderic acid C6 \\
\hline 8 & 22.78 & $\mathrm{C}_{27} \mathrm{H}_{40} \mathrm{O}_{6}$ & 459.2761 & 459.2752 & 1.96 & 441.2709 & Lucidenic acid $\mathrm{N}$ \\
\hline 9 & 23.07 & $\mathrm{C}_{30} \mathrm{H}_{44} \mathrm{O}_{8}$ & 531.2991 & 531.2963 & 5.27 & $\begin{array}{l}513.2849 \\
469.2961\end{array}$ & Ganoderic acid G \\
\hline 10 & 23.27 & $\mathrm{C}_{30} \mathrm{H}_{42} \mathrm{O}_{7}$ & 513.2864 & 513.2858 & 1.17 & 495.2737 & Ganoderenic acid B \\
\hline 11 & 23.52 & $\mathrm{C}_{30} \mathrm{H}_{44} \mathrm{O}_{7}$ & 515.2979 & 515.3014 & -6.79 & 497.2841 & Ganoderic acid B \\
\hline 12 & 23.61 & $\mathrm{C}_{29} \mathrm{H}_{40} \mathrm{O}_{8}$ & 515.2651 & 515.2650 & 0.19 & 473.2539 & Lucidenic acid E \\
\hline 13 & 23.79 & $\mathrm{C}_{32} \mathrm{H}_{44} \mathrm{O}_{9}$ & 571.2936 & 571.2913 & 4.03 & 553.2818 & Ganoderenic acid K \\
\hline 14 & 23.85 & $\mathrm{C}_{30} \mathrm{H}_{42} \mathrm{O}_{7}$ & 513.2847 & 513.2858 & -2.14 & 495.2708 & Ganoderic acid $\mathrm{AM}_{1}$ \\
\hline 15 & 23.95 & $\mathrm{C}_{32} \mathrm{H}_{46} \mathrm{O}_{9}$ & 573.3067 & 573.3069 & -0.35 & 555.2977 & Ganoderic acid K \\
\hline 16 & 24.09 & $\mathrm{C}_{30} \mathrm{H}_{42} \mathrm{O}_{8}$ & 529.2825 & 529.2807 & 3.40 & 511.2753 & $\begin{array}{c}\text { Ganoderic acid } \\
\text { derivative }\end{array}$ \\
\hline 17 & 24.25 & $\mathrm{C}_{32} \mathrm{H}_{42} \mathrm{O}_{9}$ & 569.2750 & 569.2756 & -1.05 & 551.2746 & Ganoderic acid F \\
\hline 18 & 24.32 & $\mathrm{C}_{30} \mathrm{H}_{44} \mathrm{O}_{7}$ & 515.3061 & 515.3014 & 4.12 & 497.2940 & Ganoderic acid A \\
\hline 19 & 24.49 & $\mathrm{C}_{32} \mathrm{H}_{44} \mathrm{O}_{9}$ & 571.2909 & 571.2913 & -0.70 & 553.2850 & Ganoderic acid $\mathrm{H}$ \\
\hline 20 & 24.68 & $\mathrm{C}_{30} \mathrm{H}_{40} \mathrm{O}_{8}$ & 527.2648 & 527.2650 & -0.38 & 509.2487 & Elfvingic acid A \\
\hline 21 & 24.81 & $\mathrm{C}_{27} \mathrm{H}_{38} \mathrm{O}_{6}$ & 457.2620 & 457.2596 & 5.25 & 439.2390 & Lucidenic acid A \\
\hline 22 & 24.89 & $\mathrm{C}_{30} \mathrm{H}_{44} \mathrm{O}_{6}$ & 499.3001 & 499.3065 & -6.40 & 481.3798 & Ganolucidic acid A \\
\hline 23 & 25.17 & $\mathrm{C}_{30} \mathrm{H}_{40} \mathrm{O}_{7}$ & 511.2717 & 511.2701 & 3.13 & 493.2400 & Ganoderenic acid D \\
\hline 24 & 25.31 & $\mathrm{C}_{27} \mathrm{H}_{36} \mathrm{O}_{6}$ & 455.2449 & 455.2439 & 2.20 & $\begin{array}{l}380.2072 ; \\
301.1813\end{array}$ & Lucidenic acid F \\
\hline 25 & 25.72 & $\mathrm{C}_{29} \mathrm{H}_{38} \mathrm{O}_{8}$ & 513.2508 & 513.2494 & 2.73 & 471.2400 & Lucidenic acid D \\
\hline 26 & 26.04 & $\mathrm{C}_{34} \mathrm{H}_{46} \mathrm{O}_{10}$ & 613.2997 & 613.3018 & -3.42 & $\begin{array}{l}595.2916 \\
553.2831\end{array}$ & $\begin{array}{c}\text { 3-acetylganoderic } \\
\text { acid } \mathrm{H}\end{array}$ \\
\hline 27 & 26.58 & $\mathrm{C}_{32} \mathrm{H}_{42} \mathrm{O}_{9}$ & 569.2736 & 569.2697 & 3.85 & 551.2649 & $\begin{array}{c}\text { 12-acetoxyganoderic } \\
\text { acid F }\end{array}$ \\
\hline 28 & 26.81 & $\mathrm{C}_{30} \mathrm{H}_{42} \mathrm{O}_{7}$ & 513.2859 & 513.2858 & 0.19 & 451.2844 & Ganoderic acid J \\
\hline 29 & 28.20 & $\mathrm{C}_{30} \mathrm{H}_{44} \mathrm{O}_{6}$ & 499.3089 & 499.3065 & 4.81 & 437.2981 & Ganolucidic acid D \\
\hline 30 & 31.98 & $\mathrm{C}_{30} \mathrm{H}_{44} \mathrm{O}_{5}$ & 483.3122 & 483.3116 & 1.24 & $\begin{array}{l}439.3309 \\
409.2717\end{array}$ & Ganolucidic acid E \\
\hline
\end{tabular}


Table 2. Identification of triterpenes in the G. lucidum ethanol extract.

\begin{tabular}{|c|c|c|c|c|c|c|c|c|}
\hline & A & & B & & & C & & \\
\hline Peak & Compound Name & Type & $\mathbf{R}_{1}$ & $\mathbf{R}_{2}$ & $\mathbf{R}_{3}$ & $\mathbf{R}_{4}$ & $\mathbf{R}_{5}$ & $\begin{array}{c}\text { Double } \\
\text { Bond }\end{array}$ \\
\hline 1 & 12-hydroxyganoderic acid $C_{2}$ & A & $\beta-\mathrm{OH}$ & $\beta-\mathrm{OH}$ & $\alpha-\mathrm{OH}$ & $\mathrm{OH}$ & - & \\
\hline 4 & Ganoderic acid $\eta$ & $\mathrm{C}$ & $\beta-\mathrm{OH}$ & $\beta-\mathrm{OH}$ & $=\mathrm{O}$ & $\beta-\mathrm{OH}$ & $\beta-\mathrm{OH}$ & \\
\hline 5 & 12-hydroxyganoderic acid D & A & $=\mathrm{O}$ & $\beta-\mathrm{OH}$ & $=\mathrm{O}$ & $\mathrm{OH}$ & - & \\
\hline 6 & Ganoderic acid $C_{2}$ & A & $\beta-\mathrm{OH}$ & $\beta-\mathrm{OH}$ & $\alpha-\mathrm{OH}$ & $\mathrm{H}$ & - & \\
\hline 7 & Ganoderic acid C6 & A & $\beta-\mathrm{OH}$ & $=\mathrm{O}$ & $=\mathrm{O}$ & $\beta-\mathrm{OH}$ & - & \\
\hline 8 & Lucidenic acid $\mathrm{N}$ & B & $\beta-\mathrm{OH}$ & $\beta-\mathrm{OH}$ & $=\mathrm{O}$ & $\mathrm{H}$ & - & \\
\hline 9 & Ganoderic acid G & A & $\beta-\mathrm{OH}$ & $\beta-\mathrm{OH}$ & $=\mathrm{O}$ & $\beta-\mathrm{OH}$ & - & \\
\hline 10 & Ganoderenic acid B & A & $\beta-\mathrm{OH}$ & $\beta-\mathrm{OH}$ & $=\mathrm{O}$ & $\mathrm{H}$ & - & $\Delta_{20,22}$ \\
\hline 11 & Ganoderic acid B & A & $\beta-\mathrm{OH}$ & $\beta-\mathrm{OH}$ & $=\mathrm{O}$ & $\mathrm{H}$ & - & \\
\hline 12 & Lucidenic acid E & B & $\beta-\mathrm{OH}$ & $=\mathrm{O}$ & $=\mathrm{O}$ & $\beta-\mathrm{OAc}$ & - & \\
\hline 13 & Ganoderenic acid K & A & $\beta-\mathrm{OH}$ & $\beta-\mathrm{OH}$ & $=\mathrm{O}$ & $\beta$-OAc & - & $\Delta_{20,22}$ \\
\hline 14 & Ganoderic acid $\mathrm{AM}_{1}$ & A & $\beta-\mathrm{OH}$ & $=\mathrm{O}$ & $=\mathrm{O}$ & $\mathrm{H}$ & - & \\
\hline 15 & Ganoderic acid K & A & $\beta-\mathrm{OH}$ & $\beta-\mathrm{OH}$ & $=\mathrm{O}$ & $\beta$-OAc & - & \\
\hline 17 & Ganoderic acid F & A & $=\mathrm{O}$ & $=\mathrm{O}$ & $=\mathrm{O}$ & $\mathrm{H}$ & - & \\
\hline 18 & Ganoderic acid A & A & $=\mathrm{O}$ & $\beta-\mathrm{OH}$ & $\alpha-\mathrm{OH}$ & $\mathrm{H}$ & - & \\
\hline 19 & Ganoderic acid H & A & $\beta-\mathrm{OH}$ & $=\mathrm{O}$ & $=\mathrm{O}$ & $\beta$-OAc & - & \\
\hline 20 & Elfvingic acid A & A & $=\mathrm{O}$ & $=\mathrm{O}$ & $\beta-\mathrm{OH}$ & $\alpha-\mathrm{OH}$ & - & $\Delta_{20,22}$ \\
\hline 21 & Lucidenic acid A & B & $=\mathrm{O}$ & $\beta-\mathrm{OH}$ & $=\mathrm{O}$ & $\mathrm{H}$ & - & \\
\hline 22 & Ganolucidic acid A & A & $=\mathrm{O}$ & $\mathrm{H}$ & $\alpha-\mathrm{OH}$ & $\mathrm{H}$ & - & \\
\hline 23 & Ganoderenic acid D & A & $=\mathrm{O}$ & $\beta-\mathrm{OH}$ & $=\mathrm{O}$ & $\mathrm{H}$ & - & $\Delta_{20,22}$ \\
\hline 24 & Lucidenic acid $\mathrm{F}$ & B & $=\mathrm{O}$ & $=\mathrm{O}$ & $=\mathrm{O}$ & $\mathrm{H}$ & - & \\
\hline 25 & Lucidenic acid D & B & $=\mathrm{O}$ & $=\mathrm{O}$ & $=\mathrm{O}$ & $\beta$-OAc & - & \\
\hline 26 & 3-acetylganoderic acid $\mathrm{H}$ & A & $\beta$-OAc & $=\mathrm{O}$ & $=\mathrm{O}$ & $\beta-\mathrm{OAc}$ & - & \\
\hline 27 & 12-acetoxyganoderic acid F & A & $=\mathrm{O}$ & $=\mathrm{O}$ & $=\mathrm{O}$ & $\beta-\mathrm{OAc}$ & - & \\
\hline 28 & Ganoderic acid J & A & $=\mathrm{O}$ & $=\mathrm{O}$ & $\alpha-\mathrm{OH}$ & $\mathrm{H}$ & - & \\
\hline 29 & Ganolucidic acid D & $\mathrm{C}$ & $=\mathrm{O}$ & $\mathrm{H}$ & $\alpha-\mathrm{OH}$ & $\mathrm{H}$ & $\beta-\mathrm{OH}$ & \\
\hline 30 & Ganolucidic acid E & $\mathrm{C}$ & $=\mathrm{O}$ & $\mathrm{H}$ & $\alpha-\mathrm{OH}$ & $\mathrm{H}$ & $\mathrm{H}$ & \\
\hline
\end{tabular}

\subsection{Evaluation of G. lucidum Extract Effect in HaCaT Cells}

First, we evaluated the effect of the extract on human keratinocytes. HaCaT cells were cultured with increasing concentrations of the ethanol extract and standard ganoderic acid A $\left(0-640 \mu \mathrm{g} \mathrm{mL}^{-1}\right)$ as a control for 24 and $48 \mathrm{~h}$. As reported in Figure 2, only at the highest doses did the extract show a negative effect either on cell viability evaluated by MTT (3-(4,5-dimethylthiazol-2-yl)-2,5-diphenyltetrazolium bromide) assay (Figure 2a) or on cell proliferation (BrdU incorporation, Figure 2b), in both cases comparable to the pure ganoderic acid A profile.

Interestingly, we identified an interval of concentrations ( 5 and $10 \mu \mathrm{g} \mathrm{mL}^{-1}$ ) where the G. lucidum extract induced an increase of DNA synthesis, hence stimulating cell proliferation both at $24 \mathrm{~h}$ and $48 \mathrm{~h}(p \leq 0.05)$. 
24h
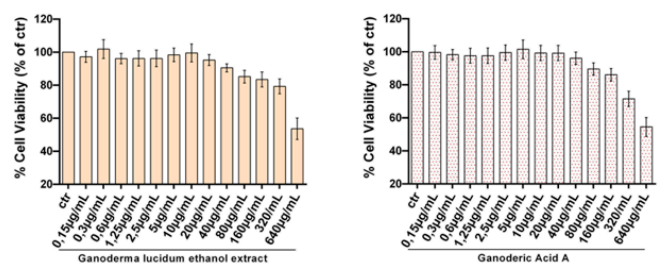

$48 \mathrm{~h}$
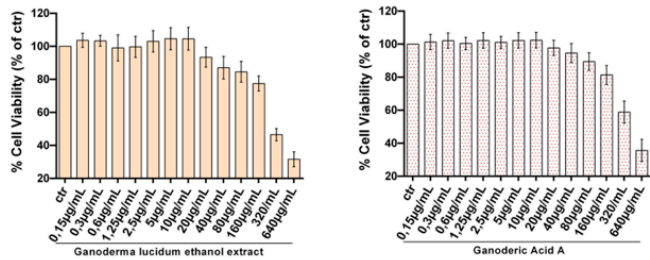

(a) 24h

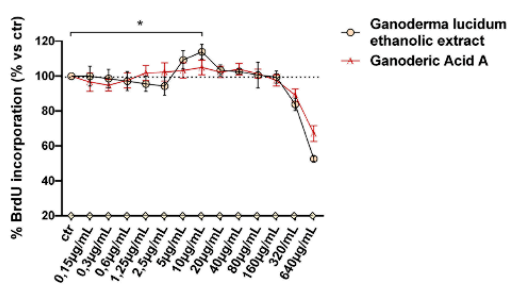

$48 \mathrm{~h}$

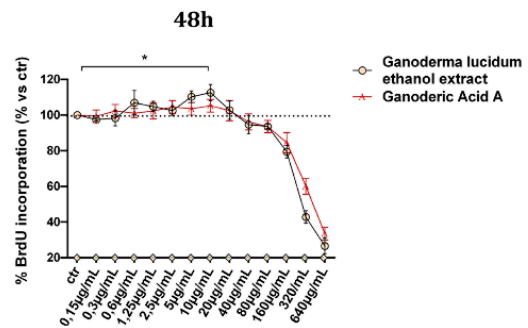

(b)

Figure 2. Evaluation of the G. lucidum extract effect in HaCaT cells: HaCaT cells were cultured for 24 or $48 \mathrm{~h}$ in the presence of the indicated concentrations $\left(0-640 \mu \mathrm{g} \mathrm{mL} \mathrm{L}^{-1}\right)$ of the G. lucidum extract or ganoderic acid A before MTT assay (a) or BrdU incorporation (b). The results are expressed as means \pm SD of independent experiments performed in triplicate and str reported as percentage vs. the untreated control (ANOVA, ${ }^{*} p<0.05$ vs. control).

\subsection{Improvement of the Migratory Capacity of Human Keratinocytes Exposed to G. lucidum Extract}

In order to assess the potential effect of G. lucidum ethanol extract on the migratory function of $\mathrm{HaCaT}$ cells, we performed a scratch wound assay (Figure 3) treatment for $24 \mathrm{~h}$ with vehicle (CTR, control) or G. lucidum ethanol extracts at five increasing concentrations $\left(0.62-10 \mu \mathrm{g} \mathrm{mL}^{-1}\right)$ in complete medium (Figure 3a).

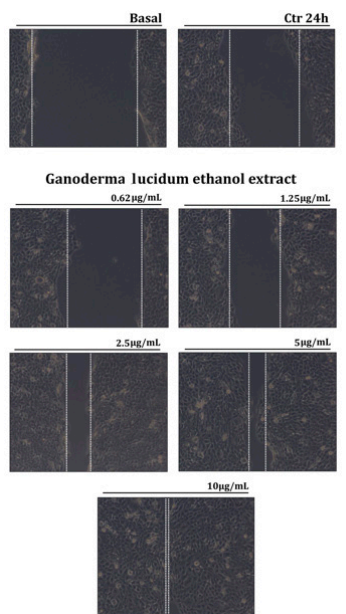

(a)

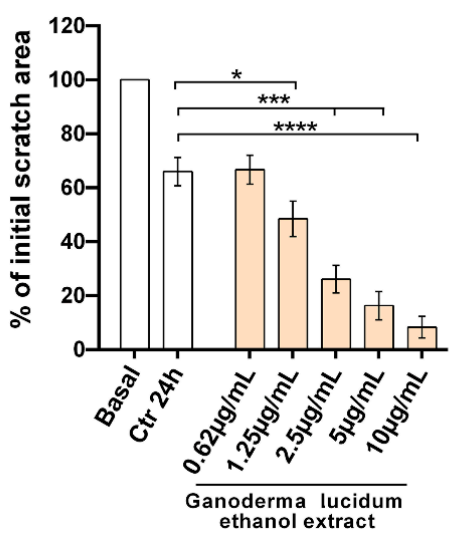

(b)

Figure 3. Improvement of the migratory capacity of human keratinocytes exposed to the G. lucidum extract: (a) wound healing assay performed in HaCaT cells treated for $24 \mathrm{~h}$ with vehicle (CTR) or G. lucidum extracts at the indicated concentrations $\left(0.62-10 \mu \mathrm{g} \mathrm{mL}{ }^{-1}\right)$ in complete medium. Representative light microscope images from three independent experiments are shown. Dotted white lines indicate the wounded area from the initial scratch. Magnification is at $\times 20$. (b) Histograms represent the mean scratch area observed in $\mathrm{HaCaT}$ cells expressed as a percent of the initial area. The measurement was made in three different experiments. The results are presented as mean \pm standard error (ANOVA, ${ }^{*} p<0.05,{ }^{* * *} p<0.001$ and ${ }^{* * *} p<0.0001$ vs. control). 
After $24 \mathrm{~h}$ of cell culture, in the presence of the G. lucidum extract, we observed an enhancement of wound healing at all doses tested from 0.62 to $10 \mu \mathrm{g} \mathrm{mL}^{-1}$, with $10 \mu \mathrm{g} \mathrm{mL}^{-1}$ being the most effective dose $\left(^{* * * *} p<0.0001\right)$, as shown in light microscope images from three independent experiments (Figure $3 a$ ) and in a histogram representation of the mean scratch area (Figure $3 b$ ).

\subsection{G. Iucidum Ethanol Extract Induces Expression of Proteins Linked to the Control of Cell Cycle and Migration}

In order to investigate the molecular pathways tuned by G. lucidum extracts in the previous experiments, we determined by Western blot analysis the status of the same proteins involved in both cell cycle progression and cell migration (Figure 4).
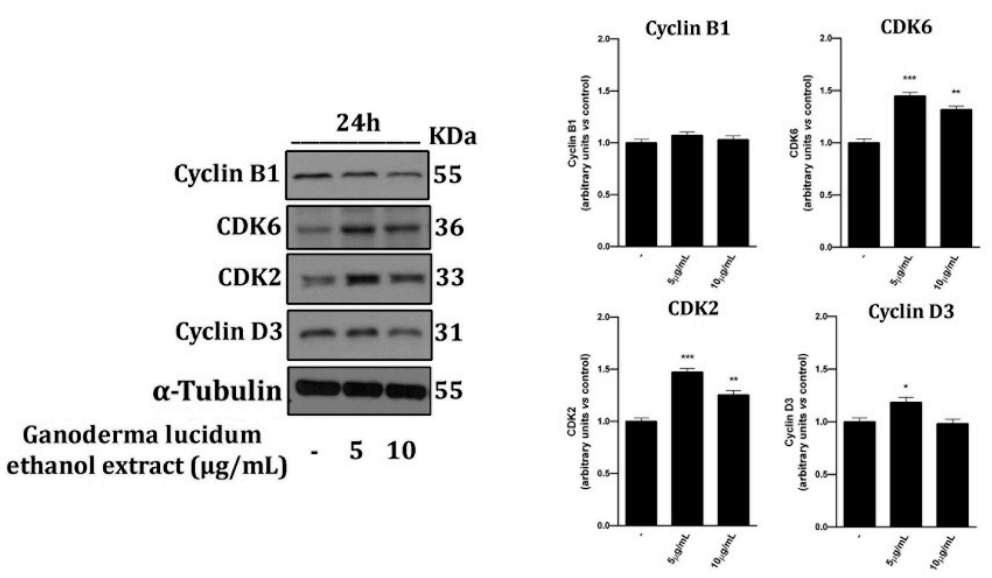

(a)
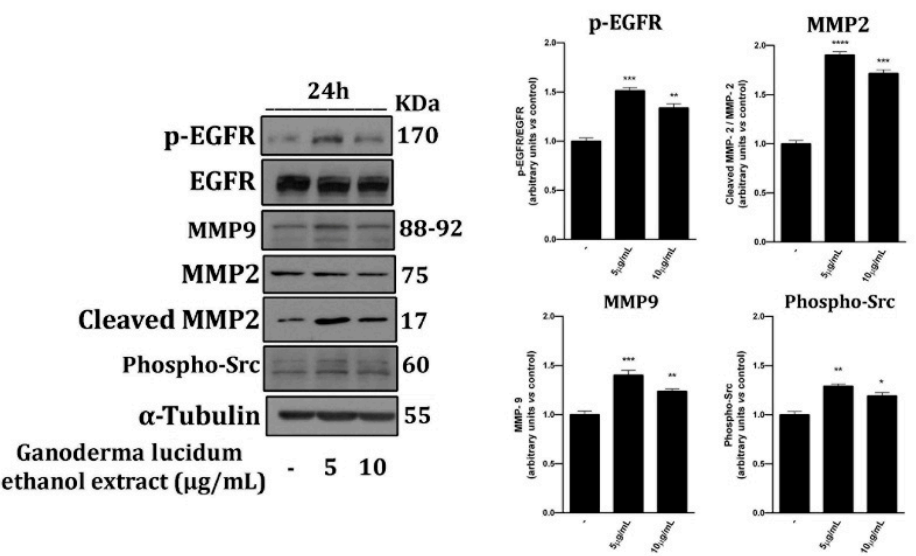

(b)

Figure 4. G. lucidum ethanol extracts induced cell cycle progression and migration protein expression. (a) Western blot analysis of cyclin B1, CDK6, CDK2 and cyclin D3 in whole cell extracts from $\mathrm{HaCaT}$ cells cultured for $24 \mathrm{~h}$ in the presence of the indicated concentrations of G. lucidum ethanol extract: Tubulin was used as a control for protein loading. The panel shows a representative Western blot of three different experiments performed with similar results. Histograms represent mean $\pm S D$ in densitometry units of scanned immunoblots from the 3 different experiments (ANOVA, ${ }^{* * *} p<0.001$, ${ }^{* *} p<0.01$ and $\left.{ }^{*} p<0.05\right)$. (b) Western blot analysis of p-EGFR (epidermal growth factor receptor), EGFR, MMP-2 (total and cleaved), MMP-9 and Phospho-Src in whole cell extracts from HaCaT cells cultured for $24 \mathrm{~h}$ in the presence of the indicated concentrations of G. lucidum ethanol extract: Tubulin was used as a control for protein loading. The panel shows a representative Western blot of three different experiments performed with similar results. Histograms represent mean $\pm \mathrm{SD}$ in densitometry units of scanned immunoblots from the 3 different experiments (ANOVA, ${ }^{* * * *} p<0.0001$, ${ }^{* * *} p<0.001$, ${ }^{* *} p<0.01$ and $\left.{ }^{*} p<0.05\right)$. 
To this end, we treated cells with the G. lucidum ethanol extract at the most effective doses, 5 and $10 \mu \mathrm{g} \mathrm{mL}^{-1}$ for $24 \mathrm{~h}$. According to the wound healing results, we observed that the G. lucidum ethanol extract increased the expression of cell cycle regulation proteins such as cyclin D3, CDK2 and CDK6 (Figure 4a). Besides, we showed that G. lucidum extracts induced MMPs, such as MMP2 (total and cleaved) and MMP9 expression (Figure $4 \mathrm{~b}$ ), and then subsequently triggered the EGRF signalling cascade. Activation of the downstream EGFR pathway, inducing phosphorylation of Src (Figure $4 \mathrm{~b}$ ), suggested that exposition to G. lucidum extracts provided a driving force in human keratinocyte migration.

\subsection{G. lucidum Ethanol Extract Ameliorates Cytotoxicity and Apoptosis Induced by $\mathrm{H}_{2} \mathrm{O}_{2}$ in $\mathrm{HaCaT}$ Cells}

$\mathrm{HaCaT}$ cells were exposed to $\mathrm{H}_{2} \mathrm{O}_{2}(0-800 \mu \mathrm{M})$ for $6 \mathrm{~h}$, and the MTT assay was used as an indicator of cell viability (Figure 5). $\mathrm{H}_{2} \mathrm{O}_{2}$ induced cytotoxicity in a dose-dependent manner. The decrease in cell viability was statistically significant at $50 \mu \mathrm{M} \mathrm{H}_{2} \mathrm{O}_{2}$, whereas cell viability was reduced to $35.4 \%$ at $200 \mu \mathrm{M} \mathrm{H}_{2} \mathrm{O}_{2}$ (Figure 5a). Scientific evidence shows that relatively low concentrations of $\mathrm{H}_{2} \mathrm{O}_{2}$ caused apoptotic death of more cells (maximal at $250 \mu \mathrm{M}$ ), whereas $1000 \mu \mathrm{M} \mathrm{H}_{2} \mathrm{O}_{2}$ resulted in a reduction in apoptosis but an increase in overall cell death [24]. Therefore, in our system, we used $200 \mu \mathrm{M}$ $\mathrm{H}_{2} \mathrm{O}_{2}$ in the subsequent experiments. We observed that at $18 \mathrm{~h}$ pretreatment of keratinocytes with the G. lucidum ethanol extract at 5 and $10 \mu \mathrm{g} \mathrm{mL} \mathrm{m}^{-1}$ protected the cells from $\mathrm{H}_{2} \mathrm{O}_{2}$-induced cytotoxicity. Cell viability declined to $35.4 \% \pm 7.3 \%$ after exposure to $200 \mu \mathrm{M} \mathrm{H}_{2} \mathrm{O}_{2}$ for $6 \mathrm{~h}$, whereas it increased to $78.6 \% \pm 3.5 \%$ and $84.2 \% \pm 4.5 \%$ with the G. lucidum extract at 5 and $10 \mu \mathrm{g} \mathrm{mL}^{-1}$ doses, respectively (Figure $5 b$ ). In order to strength the data obtained with the MTT assay, we performed a cell death analysis by annexin- $\mathrm{V}$ and propidium iodide double staining. As shown in Figure $5 \mathrm{c}$, G. lucidum pretreatment before $\mathrm{H}_{2} \mathrm{O}_{2}$ exposure resulted in a significant reduction of apoptosis and particularly of early apoptosis.

\subsection{G. lucidum Extract Prevents the Activation of Cell Death Molecular Pathways}

AKT, ERK, p53 and p21 are critical proteins involved in the control of cell response to external damages, i.e., those induced by free radicals, and are involved in apoptosis activation $[25,26]$. Aiming to elucidate cell death molecular pathways modulated by G. lucidum extract, we performed Western blot analysis of STAT3 (Signal transducer and activator of transcription 3), AKT, p53, ERK (total and phosphorylated) and p21 in whole-cell extracts from HaCaT cells (Figure 6) using hydrogen peroxide to mimic oxidative stress-induced injury (OSI) within a short period [27].

The phosphorylation status of the abovementioned and p21 proteins in $18 \mathrm{~h}$ pretreated cells with ganoderic extract at 5 and $10 \mu \mathrm{g} \mathrm{mL}^{-1}$ doses, $\mathrm{H}_{2} \mathrm{O}_{2}$ or their combination was evaluated using tubulin as a control for protein loading (Figure 6).

We observed that $\mathrm{H}_{2} \mathrm{O}_{2}$ treatment increased the levels of p-AKT, p-ERK, phospho-p53 and p21 whereas G. lucidum extract treatment partially reversed these effects significantly, preventing both activation and shutdown of STAT3 signalling, critical for cell survival [28] (Figure 6a,b). 


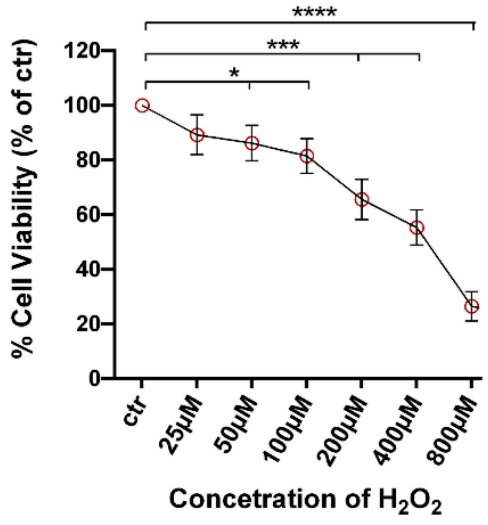

(a)

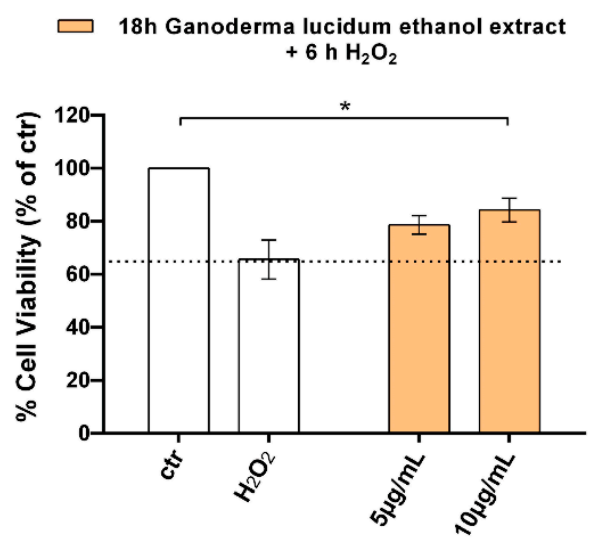

(b)

18h Ganoderma lucidum ethanol extract $+6 \mathrm{~h} \mathrm{H}_{2} \mathrm{O}_{2}$

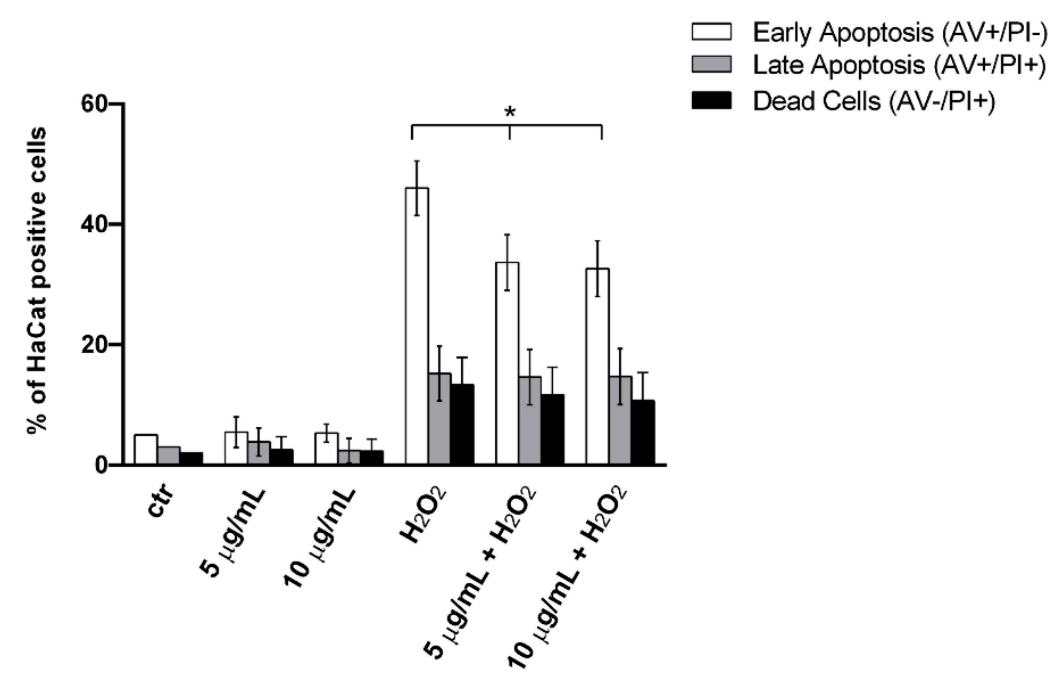

(c)

Figure 5. G. lucidum ethanol extract ameliorated cytotoxicity and apoptosis $\mathrm{H}_{2} \mathrm{O}_{2}$ induced in $\mathrm{HaCaT}$ cells: (a) HaCaT cells were cultured for $6 \mathrm{~h}$ in the presence of the indicated concentrations of $\mathrm{H}_{2} \mathrm{O}_{2}$ $(25-800 \mu \mathrm{M})$ before MTT assay. The results are expressed as means \pm SD of independent experiments performed in triplicate and are reported as percentage vs. the untreated control (ANOVA, ${ }^{*} p<0.05$, ${ }^{* * *} p<0.001$ and ${ }^{* * *} p<0.0001$ vs. control). (b) HaCaT cells were cultured for $18 \mathrm{~h}$ in the presence of the indicated concentrations $\left(0,5\right.$ and $\left.10 \mu \mathrm{g} \mathrm{mL}^{-1}\right)$ of the $\mathrm{G}$. lucidum ethanol extract before treatment with $\mathrm{H}_{2} \mathrm{O}_{2}$ for $6 \mathrm{~h}$. The results are expressed as means $\pm \mathrm{SD}$ of independent experiments performed in triplicate and are reported as percentage vs. the untreated control (ANOVA, ${ }^{*} p<0.05$ vs. control). (c) Flow cytometric analysis of annexin V and propidium iodide (PI) double staining in the G. lucidum ethanol extract-treated $\mathrm{HaCaT}$ cells after $18 \mathrm{~h}$ and $\mathrm{H}_{2} \mathrm{O}_{2}$ for $6 \mathrm{~h}$ : histograms indicate the total percentage of early (annexin V-positive cells/PI-negative cells) and late apoptotic events (annexin V/PI-double positive cells) as well as necrotic cells (annexin V-negative cells/PI-positive cells). The results are representative of four independent experiments performed in duplicate and are expressed as mean \pm SD (ANOVA, $\left.{ }^{*} p<0.05\right)$. 


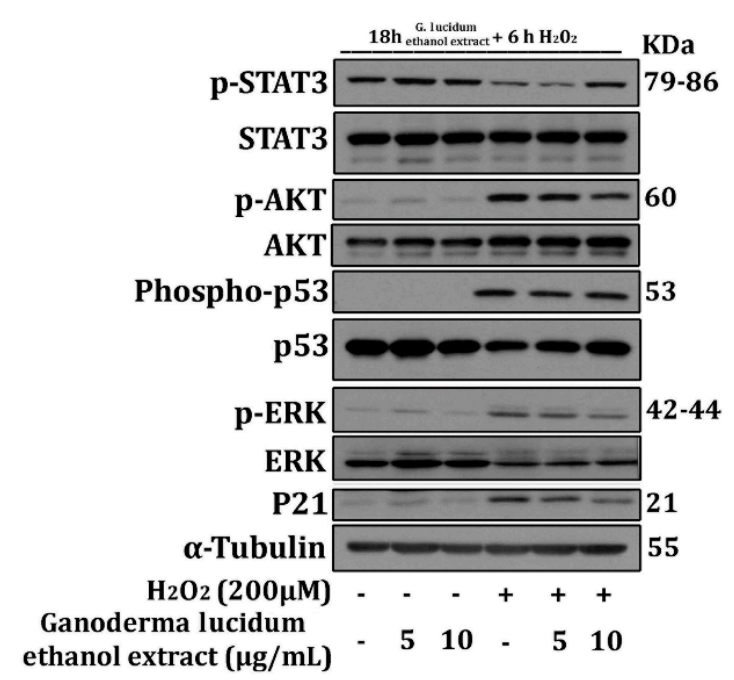

(a)

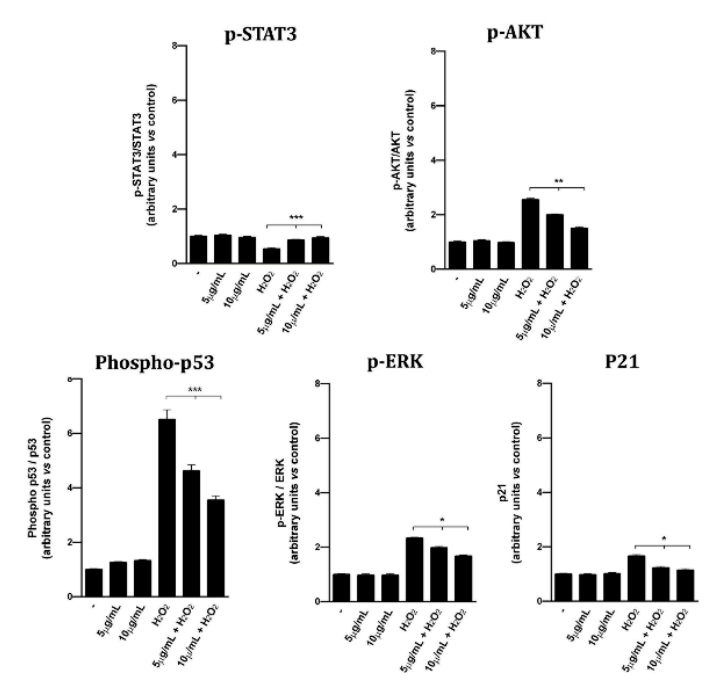

(b)

Figure 6. Ganonderic acid extract prevented the activation of cell death molecular pathways. (a) Western blot analysis of STAT3, AKT, p53, ERK (total and phosphorylated) and p21 in whole cell extracts from $\mathrm{HaCaT}$ cells cultured for $18 \mathrm{~h}$ in the presence of the indicated concentrations of the G. lucidum ethanol extract and $\mathrm{H}_{2} \mathrm{O}_{2}$ for $6 \mathrm{~h}$ : Tubulin was used as a control for protein loading. The panel shows a representative Western blot of three different experiments performed with similar results. (b) Histograms represent mean \pm SD in densitometry units of scanned immunoblots from the 3 different experiments (ANOVA, ${ }^{* * *} p<0.001,{ }^{* *} p<0.01$ and ${ }^{*} p<0.05$ ).

\section{Discussion}

Bioactive extracts from G. lucidum only recently have been reported to present remarkable in vitro and in vivo pharmacological properties beneficial also to the development of cosmeceutical formulations [21]. However, despite the commercial success, the pharmacological efficacy, especially in the field of cosmetic dermatology, still needs more in-depth scientific support. Lately, an in vitro analysis of the G. lucidum ethanolic extract as a dermatological ingredient was carried out, showing its suitability for skincare formulations as the absence of toxicity in keratinocytes and fibroblasts $[28,29]$.

In this context, the present study reported the effect of G. lucidum on human keratinocytes as an in vitro skin model for evaluation of its dermatological properties which can be transferred to the cosmetics field for cosmetic use or to the therapeutic field for possible medical applications.

The ethanol extraction of G. lucidum was selected and listed as the most robust and suitable extraction method for this class of natural compounds [30,31], and detailed identification, characterization of chemical structures and quantification of triterpenes by UHPLC-ESI-IT-TOF analysis were performed for a detailed molecular description. In vitro studies on cultures of human keratinocytes were conducted by comparing G. ludicum extract activity with ganoderic acid A, the main G. lucidum described bioactive compound and mostly present in skin products available on the market $[9,32,33]$. Once the lack of cytotoxicity by G. lucidum ethanol extract was confirmed, we identified an interval of concentrations $\left(5\right.$ and $\left.10 \mu \mathrm{g} \mathrm{mL}^{-1}\right)$ for the induction of cellular DNA synthesis, hence stimulating cell proliferation only for the G. lucidum ethanol extract, with respect to gandoreic acid A. This activity, observed only for the G. lucidum ethanol extract, might be ascribed to other bioactive ganoderic acids present in lower quantities or also might be attributable to a synergistic effect of various active components present in the ethanol extract.

Importantly, additional lines of evidence of this proliferation induction by G. lucidum ethanol extract treatment indicate an increase of the cyclin-dependent kinase protein expressions, mainly CDK2 and CDK6 (Figure 4a), key components of the cell cycle machinery for G1 to S transition.

To evaluate if G. lucidum ethanol extract treatment could be helpful for skin care, from minor, superficial and basic skin injuries to more complicated pathological states such as ulcers or bedsores, 
pathologies which, in addition to cell proliferation, also required suitable cell migration [34], we evaluated whether the extract treatment influenced the expression and activity of proteins involved in cell migration. Furthermore, we reported an increase of the migration rate supported by activation of the matrix metalloproteinases (MMPs), specifically MMP-2 and MMP-9; the pathways downstream EGFR stimulation; and phospho-Src (Figure 4b), important factors for stimulation of cell migration and normal tissue remodelling $[35,36]$. These results were confirmed by the functional wound healing assay at all doses tested from 0.62 to $10 \mu \mathrm{g} \mathrm{mL}^{-1}$, with $10 \mu \mathrm{g} \mathrm{mL} \mathrm{L}^{-1}$ being the most effective dose (Figure $3 \mathrm{a}, \mathrm{b}$ ).

Since oxidative stress plays a crucial role in several diseases pathogenesis, including allergic and inflammatory skin diseases like atopic dermatitis, urticaria and psoriasis [37], and in skin aging and since regulation of reactive oxygen species (ROS) levels is essential for maintenance of healthy skin homeostasis [38], we investigated whether the G. lucidum extract was able to protect cells from $\mathrm{H}_{2} \mathrm{O}_{2}$-induced cytotoxicity. In our system, $6 \mathrm{~h}$ exposure of $200 \mu \mathrm{M} \mathrm{H}_{2} \mathrm{O}_{2}$ reduced more than $35 \%$ of cell viability; thus, this concentration was used in subsequent experiments. The G. lucidum ethanol extract at 5 and $10 \mu \mathrm{g} \mathrm{mL}^{-1}$ doses reverted this trend, reducing the oxidative stress-induced injury to $15 \%$ (Figure $5 \mathrm{~b}$ ). These data were corroborated by annexin- $\mathrm{V}$ and propidium iodide double staining cell death analysis, which showed that G. lucidum pretreatment before $\mathrm{H}_{2} \mathrm{O}_{2}$ exposure resulted in a significant reduction of apoptosis, particularly of early apoptosis (Figure $5 \mathrm{c}$ ). To elucidate cell death molecular pathways modulated by G. lucidum extract, we performed Western blot analysis of STAT3, AKT, p53, ERK (total and phosphorylated) and p21 in whole-cell extracts from HaCaT cells pretreated for $18 \mathrm{~h}$ with the ganoderic extract (Figure 6) using $\mathrm{H}_{2} \mathrm{O}_{2}$ to mimic OSI within a short time period. We observed that $\mathrm{H}_{2} \mathrm{O}_{2}$ treatment increased the levels of p-AKT, p-ERK, phospho-p53 and p21.

Our study confirmed that pretreatment with G. lucidum extracts partially reversed these effects, significantly preventing both activation and shutdown of STAT3 signalling involved in cell damage and apoptosis activation (Figure $6 a, b)$. These data suggested that ERK signalling plays a critical role in the induction of survival, migration and proliferation in G. lucidum extract-treated cells and that protective effects against OSI, at least partially, depended upon STAT3 inhibition.

Our results, confirming what is already reported in scientific literature for the antioxidant activity of the G. lucidum extract [39] in addition to its anticancer, antimicrobial and anti-inflammatory activities [39,40], provide the first evidence of an increase in cell migration and an accelerated healing process and, at the same time, show the proteins involved and the possible molecular mechanisms in these activities.

\section{Materials and Methods}

\subsection{Chemicals and Materials}

The fruiting bodies of G. lucidum were provided by Indena S.p.A. (Viale Ortles 12, 20139 Milan, Italy) as dry material. Ganoderic acid A was purchased from Sigma-Aldrich Inc. (St. Luis, MO, USA). The G. lucidum extract was solubilized in dimethyl sulfoxide (DMSO) ( $0.01 \%$ in our assays) and added to cell cultures at the reported concentrations. $\mathrm{H}_{2} \mathrm{O}_{2}$ was purchased from Sigma-Aldrich (Milan, Italy). For Western blot analysis, the following antibodies were used: mouse monoclonal antihuman $\alpha$-Tubulin, rabbit polyclonal antihuman phospho-STAT3 (p-STAT3; Tyr705), rabbit monoclonal antihuman STAT3, rabbit monoclonal antihuman phospho-p44/42 MAPK (p-Erk1/2; Thr202/Tyr204), rabbit monoclonal antihuman p44/42 MAPK (Erk1/2), rabbit monoclonal antihuman phospho-Akt (p-Akt; Ser473), rabbit monoclonal antihuman Akt, rabbit polyclonal p53, rabbit polyclonal antibody to phosphorylated p53, rabbit monoclonal antihuman p21, mouse monoclonal antihuman CDK6, rabbit monoclonal antihuman CDK2, mouse monoclonal antihuman cyclin D3, rabbit monoclonal antihuman phospho-EGFR (p-EGFR; Tyr1068) and rabbit monoclonal antihuman EGF receptor were purchased from Cell Signaling Technology (Danvers, MA, USA). Mouse monoclonal MMP2, mouse monoclonal antihuman MMP9, rabbit polyclonal antihuman Src (phospho Y418) and rabbit monoclonal antihuman cyclin B1 were purchased from Abcam (Cambridge, UK). Secondary HRP (Horseradish Peroxidase)-linked goat 
anti-mouse or goat anti-rabbit IgG were also purchased from Cell Signaling Technology (Danvers, MA, USA).

\subsection{Sample Preparation}

The dried powder of G. lucidum ( $3 \mathrm{~g}$ ) was extracted with $100 \mathrm{~mL}$ of ethanol by refluxing in a Soxhlet apparatus for $6 \mathrm{~h}$, and the solvent was evaporated under reduced pressure. The dried ethanol residue was then extracted with ethyl acetate three times. Finally, the ethyl acetate fractions were combined, filtered, evaporated and lyophilized for $24 \mathrm{~h}$ (LyoQuest-55, Telstar Technologies, Terrassa, Spain), using condenser temperature at $-52^{\circ} \mathrm{C}$ and $0.100 \mathrm{mBar}$ as vacuum value [30].

\subsection{LCMS-IT-TOF Analysis of G. lucidum Extract}

A Shimadzu Nexera UHPLC system consisting of a SIL-30AC autosampler, a CBM-20A controller, a DGU-20 AR5 degasser, two LC-30AD pumps, a CTO-20AC column oven and an SPD-M20A photodiode array detector was used for UHPLC-ESI-IT-TOF analyses. The UHPLC system was coupled online to an LCMS-IT-TOF mass spectrometer through an ESI source (Shimadzu, Kyoto, Japan). LC-MS data elaboration was performed by the LCMSsolution ${ }^{\circledR}$ software (Version 3.50.346, Shimadzu).

LC-MS analysis of the G. lucidum extract was carried out on Kinetex ${ }^{\circledR}$ C18 $150 \times 2.1 \mathrm{~mm}(100 \AA)$, packed with $2.6 \mu \mathrm{m}$ core-shell particles column (Phenomenex, Bologna, Italy). The injection volume was $2 \mu \mathrm{L}$, and the flow rate was $0.5 \mathrm{~mL} \mathrm{~min}^{-1}$. The temperature of the column oven was set to $40{ }^{\circ} \mathrm{C}$. The following PDA parameters were applied: sampling rate, $12.5 \mathrm{~Hz}$; detector time constant, $0.240 \mathrm{~s}$; and cell temperature, $40^{\circ} \mathrm{C}$. Data acquisition was set in the range $190-400 \mathrm{~nm}$, and chromatograms were monitored at $254 \mathrm{~nm}$ at maximum absorbance of the compounds of interest. The mobile phase consisted of $\mathrm{H}_{2} \mathrm{O}(\mathrm{A})$ and $\mathrm{ACN}(\mathrm{B})$, both acidified by formic acid $0.1 \% v / v$. The analysis was performed in gradient elution as follows: $0.01-5.00 \mathrm{~min}$, isocratic to $1 \% \mathrm{~B} ; 5.01-53.00 \mathrm{~min}, 1-95 \% \mathrm{~B} ; 53.01-56.00 \mathrm{~min}$, isocratic to $95 \% \mathrm{~B}$; then four minutes for column re-equilibration.

Negative ionization mode was used for MS detection operating with the following parameters: detector voltage, $1.65 \mathrm{kV}$; CDL (Curved Desolvation Line) temperature, $250^{\circ} \mathrm{C}$; block heater temperature, $250{ }^{\circ} \mathrm{C}$; nebulizing gas flow $\left(\mathrm{N}_{2}\right), 1.5 \mathrm{~L} / \mathrm{min}$; and drying gas pressure, $100 \mathrm{kPa}$. Full scan MS data were acquired in the range of 150-1600 m/z (ion accumulation time, $30 \mathrm{~ms}$; IT (Ion trap) repeat $=2$ ). MS/MS experiments were conducted in the data-dependent acquisition, and precursor ions were acquired in the range 100-1200 m/z; ion accumulation time, $60 \mathrm{~ms}$; CID (Collision Induced Dissociation) energy, $50 \%$; collision gas, $50 \%$; repeat $=1$; execution trigger (BPC Base Peak Chromatogram) intensity, at the $70 \%$ stop level.

Identification was carried out based on standard retention time and UV spectra and by comparing MS/MS data with those present in the literature [30]. Molecular formulas were calculated by the Formula Predictor software (Version 1.12, Shimadzu), setting a low tolerance so that most of the identified compounds were in position 1 in the list of possible candidates.

\subsection{Quantitative Analysis}

As an external standard, we chose ganoderic acid A for quantification of triterpenes in the G. lucidum ethanol extract. The stock solution $\left(1 \mathrm{mg} \mathrm{mL}^{-1}\right)$ was prepared in ethanol, the calibration curve was obtained in a concentration range of $200-0.5 \mu \mathrm{g} \mathrm{mL}^{-1}$ with seven concentration levels (200, $50,25,10,5,1$ and $0.5 \mu \mathrm{g} \mathrm{mL}^{-1}$ ) and triplicate injections of each level were run. Peak areas of ganoderic acid A were plotted against corresponding concentrations $\left(\mu \mathrm{g} \mathrm{mL}^{-1}\right)$. The amount of compounds in the sample was expressed as milligram per gram of dried extract, and linear regression was used to generate calibration curve with $r^{2}$ values $\geq 0.9999$. Limits of detection (LOD) and quantification (LOQ) were calculated by the ratio between the standard deviation (SD) and the analytical curve slope multiplied by 3.3 and 10, respectively. 


\subsection{Cells}

Human immortalized keratinocytes (HaCaT) were grown in Dulbecco's modified Eagle's medium (DMEM, GIBCO, Grand Island, NY, USA) and supplemented as described in detail elsewhere [41]. HaCaT cells were kindly provided by Giuseppe Monfrecola (Department of Experimental Dermatology, University of Naples, Naples, Italy).

All cell cultures were maintained at $37^{\circ} \mathrm{C}$ in a humidified $5 \% \mathrm{CO}_{2}$ atmosphere.

\subsection{Determination of Cells Viability, MTT Assay}

$\mathrm{HaCaT}$ cells $\left(6 \times 10^{3} /\right.$ well $)$ were cultured for $24 \mathrm{~h}$ into 96 -well plates before the addition of the individual substances at the indicated concentrations and were cultured for an additional $24-48 \mathrm{~h}$ at $37^{\circ} \mathrm{C}$. The reduction of the MTT (3-(4, 5-dimethylthiazolyl-2)-2, 5-diphenyltetrazolium bromide) tetrazolium salts assay was employed to examine cells' viability, as described in detail elsewhere [42]. All experiments were performed in triplicate, and the relative cell viability was expressed as a percentage in comparison with the untreated control cells.

\subsection{Determination of Cells Proliferation, BrdU Assay}

$\mathrm{HaCaT}$ cells $\left(6 \times 10^{3} /\right.$ well $)$ were cultured for $24 \mathrm{~h}$ into 96 -well plates before the addition of the G. lucidum ethanol extract or ganoderic acid-A at the indicated concentrations and were cultured for an additional $24-48 \mathrm{~h}$ at $37^{\circ} \mathrm{C}$. Cell proliferation was evaluated by measuring BrdU incorporation into DNA (BrdU colorimetric assay kit; Roche Applied Science, South San Francisco, CA, USA) and was determined by an ELISA plate reader (ThermoScientific, Waltham, MA, USA) at $450 \mathrm{~nm}$ as described in detail elsewhere [43]. All experiments were performed in triplicate, and the relative cell growth was expressed as percentage in comparison with the untreated control cells $(100 \%)$.

\subsection{Scratch Wound Healing Assay}

To evaluate the effect of G. lucidum extracts on HaCaT cell migration, the cells were plated in 6-well plates at a density of $5 \times 10^{3}$ cells/well. When the confluent cells formed a homogeneous carpet and a vertical wound in the wells using a $200 \mu \mathrm{L}$ tip was performed, culture medium containing G. lucidum extracts at the indicated concentrations or the vehicle alone was added to the wells, after the removal of detached cells. The wound area was recorded immediately and after $24 \mathrm{~h}$ through microscope analysis, as previously described [41].

\subsection{Apoptosis Analysis}

Quantitative assessment of apoptosis of HaCaT cells was analysed by antihuman annexin $\mathrm{V}$ (BioLegend, San Diego, CA, USA) using propidium iodide solution (PI) staining. Briefly, cells grown in 100-mm dishes for $24 \mathrm{~h}$ with $\mathrm{G}$. lucidum extracts, $\mathrm{H}_{2} \mathrm{O}_{2}$ or combined as indicated were harvested with trypsin, washed in phosphate buffer saline (PBS) and subjected to apoptosis determination by the procedure described in detail elsewhere [43].

\subsection{Western Blot Analysis}

Cells were grown in p60 tissue culture plates at a density of $2 \times 10^{4}$ cells $/ \mathrm{cm}^{2}$ for $24 \mathrm{~h}$. Cells were then incubated with vehicle, G. lucidum extracts (for $24 \mathrm{~h}$ ), $\mathrm{H}_{2} \mathrm{O}_{2}$ (for $6 \mathrm{~h}$ ) or their combination (G. lucidum extracts for $18 \mathrm{~h}$ and $\mathrm{H}_{2} \mathrm{O}_{2}$ for an additional $6 \mathrm{~h}$ ), as indicated. After incubation, cells were washed with PBS, harvested and lysed in ice-cold RIPA lysis buffer $(50 \mathrm{mM}$ Tris-HCl, $150 \mathrm{mM} \mathrm{NaCl}$, $0.5 \%$ Triton $\mathrm{X}-100,0.5 \%$ deoxycholic acid, $10 \mathrm{mg} \mathrm{mL}^{-1}$ leupeptin, $2 \mathrm{mM}$ phenylmethylsulfonyl fluoride and $10 \mathrm{mg} \mathrm{mL}^{-1}$ aprotinin) and then assayed for Western blot by the procedure, which is described in detail elsewhere [44]. 


\subsection{Statistical Analysis}

Statistical analysis was performed in all experiments shown by using the GraphPad Prism 6.0 software for Windows (GraphPad software). For each type of assay or phenotypic analysis, data obtained from multiple experiments are calculated as mean \pm SD and analysed for statistical significance using the 2-tailed Student $t$-test for independent groups or using ANOVA followed by Bonferroni correction for multiple comparisons. $p$ values less than 0.05 were considered significant. ${ }^{*} p<0.05$, ** $p<0.01$ and ${ }^{* * *} p<0.001$.

\section{Conclusions}

We provided the first scientific evidence that $G$. lucidum ethanol extract due to its high content in triterpenes remarkably increased cell migration patterns and accelerated the healing process, principally enhancing re-epithelialization and, at the same time, protecting the skin from the action of free radicals, paving the way for possible medical applications. Moreover, the prevention of skin aging leads to considering its formulations attractive as cosmeceuticals. Additional in vivo and clinical studies are requested to develop and validate novel nutraceuticals, cosmeceuticals and pharmacological formulations.

Author Contributions: M.A. and G.P. wrote the paper, designed and conducted the research, and analysed and interpreted data; M.G.B. and V.C. performed the research; R.R. and S.P. analysed data and reviewed the paper critically; A.M.D., M.B. and W.C. provided important suggestions including some reagents along with critical reading of the paper; S.P., M.B., P.C. and M.R. provided financial support to the project; P.C. and M.R. were fully responsible for the study design and supervised the project in its entirety. All authors have read and agreed to the published version of the manuscript.

Funding: This research was funded supported by "Nutraceutica e cosmeceutica come strumenti di tutela della salute dell'uomo"-CUP: B48I17000160008-COR: 652124-F/050127/03/X32; Fondo per la Crescita Sostenibile-Horizon 2020 PON “IMPRESE E COMPETITIVITA" 2014-2020 FESR; and Associazione Italiana Ricerca sul Cancro (AIRC; IG 13312, IG 18999, AIRC and Fondazione Cariplo TRIDEO 2015 No. 17216).

Conflicts of Interest: The authors declare no conflict of interest.

\section{References}

1. Wachtel-Galor, S.; Yuen, J.; Buswell, J.A.; Benzie, I.F.F. Ganoderma Lucidum (Lingzhi or Reishi) Herbal Medicine: Biomolecular and Clinical Aspects, 2nd ed.; Taylor and Francis Group: Milton Park, UK, 2011.

2. Chu, T.T.; Benzie, I.F.; Lam, C.W.; Fok, B.S.; Lee, K.K.; Tomlinson, B. Study of potential cardioprotective effects of Ganoderma lucidum (Lingzhi): Results of a controlled human intervention trial. Br. J. Nutr. 2012, 107, 1017-1027. [CrossRef] [PubMed]

3. Yuen, J.W.; Gohel, M.D. Anticancer effects of Ganoderma lucidum: A review of scientific evidence. Nutr. Cancer 2005, 53, 11-17. [CrossRef] [PubMed]

4. Wu, Y.L.; Han, F.; Luan, S.S.; Ai, R.; Zhang, P.; Li, H.; Chen, L.X. Triterpenoids from Ganoderma lucidum and Their Potential Anti-inflammatory Effects. J. Agric. Food Chem. 2019, 67, 5147-5158. [CrossRef] [PubMed]

5. Lu, S.Y.; Peng, X.R.; Dong, J.R.; Yan, H.; Kong, Q.H.; Shi, Q.Q.; Li, D.S.; Zhou, L.; Li, Z.R.; Qiu, M.H. Aromatic constituents from Ganoderma lucidum and their neuroprotective and anti-inflammatory activities. Fitoterapia 2019, 134, 58-64. [CrossRef] [PubMed]

6. Cuong, V.T.; Chen, W.; Shi, J.; Zhang, M.; Yang, H.; Wang, N.; Yang, S.; Li, J.; Yang, P.; Fei, J. The anti-oxidation and anti-aging effects of Ganoderma lucidum in Caenorhabditis elegans. Exp. Gerontol. 2019, 117, 99-105. [CrossRef] [PubMed]

7. Wang, J.; Cao, B.; Zhao, H.; Feng, J. Emerging Roles of Ganoderma Lucidum in Anti-Aging. Aging Dis. 2017, 8, 691-707. [CrossRef]

8. Bishop, K.S.; Kao, C.H.J.; Xu, Y.; Glucina, M.P.; Paterson, R.R.M.; Ferguson, L.R. From 2000 years of Ganoderma lucidum to recent developments in nutraceuticals. Phytochemistry 2015, 114, 56-65. [CrossRef]

9. Liang, C.; Tian, D.; Liu, Y.; Li, H.; Zhu, J.; Li, M.; Xin, M.; Xia, J. Review of the molecular mechanisms of Ganoderma lucidum triterpenoids: Ganoderic acids A, C2, D, F, DM, X and Y. Eur. J. Med. Chem. 2019, 174, 130-141. [CrossRef] 
10. Zhao, X.R.; Zhang, B.J.; Deng, S.; Zhang, H.L.; Huang, S.S.; Huo, X.K.; Wang, C.; Liu, F.; Ma, X.C. Isolation and identification of oxygenated lanostane-type triterpenoids from the fungus Ganoderma lucidum. Phytochem. Lett. 2016, 16, 87-91. [CrossRef]

11. Liu, Z.; Xing, J.; Zheng, S.; Bo, R.; Luo, L.; Huang, Y.; Niu, Y.; Li, Z.; Wang, D.; Hu, Y.; et al. Ganoderma lucidum polysaccharides encapsulated in liposome as an adjuvant to promote Th1-bias immune response. Carbohydr. Polym. 2016, 142, 141-148. [CrossRef]

12. Baby, S.; Johnson, A.J.; Govindan, B. Secondary metabolites from ganoderma. Phytochemistry 2015, 114, 66-101. [CrossRef] [PubMed]

13. Li, L.; Wang, H.H.; Nie, X.T.; Jiang, W.R.; Zhang, Y.S. Sodium butyrate ameliorates lipopolysaccharide-induced cow mammary epithelial cells from oxidative stress damage and apoptosis. J. Cell. Biochem. 2018, 120, 2370-2381. [CrossRef] [PubMed]

14. Kladar, N.V.; Gavarić, N.S.; Božin, B.N. Ganoderma: Insights into anticancer effects. Eur. J. Cancer Prev. 2016, 25, 462-471. [CrossRef] [PubMed]

15. Li, H.; Lou, B.; Zhang, Y.; Zhang, C. Ganoderic Acid A exerts the cytoprotection against hypoxia-triggered impairment in PC12 cells via elevating microRNA-153. Phytother. Res. 2020, 34, 640-648. [CrossRef] [PubMed]

16. Wong, K.L.; Chao, H.H.; Chan, P.; Chang, L.P.; Liu, C.F. Antioxidant activity of Ganoderma lucidum in acute ethanol-induced heart toxicity. Phytother. Res. 2004, 18, 1024-1026. [CrossRef]

17. Ruan, W.; Wei, Y.; Popovich, D.G. Distinct Responses of Cytotoxic Ganoderma lucidum Triterpenoids in Human Carcinoma Cells. Phytother. Res. 2015, 29, 1744-1752. [CrossRef] [PubMed]

18. Van Nguyen, T.; Tung, N.T.; Cuong, T.D.; Hung, T.M.; Kim, J.A.; Woo, M.H.; Choi, J.S.; Lee, J.H.; Min, B.S. Cytotoxic and anti-angiogenic effects of lanostane triterpenoids from Ganoderma lucidum. Phytochem. Lett. 2015, 12, 69-74. [CrossRef]

19. Stojkovic, D.S.; Barros, L.; Calhelha, R.C.; Glamoclija, J.; Ciric, A.; van Griensven, L.J.; Sokovic, M.; Ferreira, I.C. A detailed comparative study between chemical and bioactive properties of Ganoderma lucidum from different origins. Int. J. Food Sci. Nutr. 2014, 65, 42-47. [CrossRef]

20. Wu, Y.; Choi, M.H.; Li, J.; Yang, H.; Shin, H.J. Mushroom cosmetics: The present and future. Cosmetics 2016, 3, 22. [CrossRef]

21. Guo, W.L.; Pan, Y.Y.; Li, L.; Li, T.T.; Liu, B.; Lv, X.C. Ethanol extract of Ganoderma lucidum ameliorates lipid metabolic disorders and modulates the gut microbiota composition in high-fat diet fed rats. Food Funct. 2018, 9, 3419-3431. [CrossRef]

22. Taofiq, O.; Gonzalez-Paramas, A.M.; Martins, A.; Barreiro, M.F.; Ferreira, I.C. Mushrooms extracts and compounds in cosmetics, cosmeceuticals and nutricosmetics-A review. Ind. Crops Prod. 2016, 90, 38-48. [CrossRef]

23. Taofiq, O.; Martins, A.; Barreiro, M.F.; Ferreira, I.C. Mushrooms Anti-inflammatory potential of mushroom extracts and isolated metabolites. Trends Food Sci. Technol. 2016, 50, 193-210. [CrossRef]

24. Turner, N.A.; Xia, F.; Azhar, G.; Zhang, X.; Liu, L.; Wei, J.Y. Oxidative stress induces DNA fragmentation and caspase activation via the c-Jun NH2-terminal kinase pathway in H9c2 cardiac muscle cells. J. Mol. Cell. Cardiol. 1998, 30, 1789-1801. [CrossRef] [PubMed]

25. Wang, J.; Qi, C.; Liu, L.; Zhao, L.; Cui, W.; Tian, Y.; Liu, B.; Li, J. Taurine Protects Primary Neonatal Cardiomyocytes Against Apoptosis Induced by Hydrogen Peroxide. Int. Heart J. 2018, 59, 190-196. [CrossRef] [PubMed]

26. Jin, G.F.; Hurst, J.S.; Godley, B.F. Hydrogen peroxide stimulates apoptosis in cultured human retinal pigment epithelial cells. Curr. Eye Res. 2001, 22, 165-173. [CrossRef] [PubMed]

27. Duan, W.; Yang, Y.; Yi, W.; Yan, J.; Liang, Z.; Wang, N.; Li, Y.; Chen, W.; Yu, S.; Jin, Z.; et al. New Role of JAK2/STAT3 Signaling in Endothelial Cell Oxidative Stress Injury and Protective Effect of Melatonin. PLoS ONE 2013, 8, e57941. [CrossRef] [PubMed]

28. Zhang, Y.; Wang, D.; Xu, J.; Wang, Y.; Ma, F.; Li, Z.; Liu, N. Stat3 activation is critical for pluripotency maintenance. J. Cell. Physiol. 2018, 234, 1044-1051. [CrossRef]

29. Taofiq, O.; Rodrigues, F.; Barros, L.; Barreiro, M.F.; Ferreira, I.C.; Oliveira, M. Mushroom ethanolic extracts as cosmeceuticals ingredients: Safety and ex vivo skin permeation studies. Food Chem. Toxicol. 2019, 127, 228-236. [CrossRef] 
30. Taofiq, O.; Heleno, S.A.; Calhelha, R.C.; Alves, M.J.; Barros, L.; Gonzalez-Paramas, A.M.; Barreiro, M.F.; Ferreira, I.C. The potential of Ganoderma lucidum extracts as bioactive ingredients in topical formulations, beyond its nutritional benefits. Food Chem. Toxicol. 2017, 108 Pt A, 139-147. [CrossRef]

31. Ruan, W.; Lim, A.H.; Huang, L.G.; Popovich, D.G. Extraction optimisation and isolation of triterpenoids from Ganoderma lucidum and their effect on human carcinoma cell growth. Nat. Prod. Res. 2014, 28, 2264-2272. [CrossRef]

32. Chang, Y.; Kong, R. Ganoderic acid A alleviates hypoxia-induced apoptosis, autophagy, and inflammation in rat neural stem cells through the PI3K/AKT/mTOR pathways. Phytother. Res. 2019, 33, 1448-1456. [CrossRef] [PubMed]

33. Cao, F.R.; Feng, L.; Ye, L.H.; Wang, L.S.; Xiao, B.X.; Tao, X.; Chang, Q. Ganoderic Acid A Metabolites and Their Metabolic Kinetics. Front. Pharmacol. 2017, 8, 101. [CrossRef] [PubMed]

34. Long, M.; Cai, L.; Li, W.; Zhang, L.; Guo, S.; Zhang, R.; Zheng, Y.; Liu, X.; Wang, M.; Zhou, X.; et al. DPP-4 Inhibitors Improve Diabetic Wound Healing via Direct and Indirect Promotion of Epithelial-Mesenchymal Transition and Reduction of Scarring. Diabetes 2018, 67, 518-531. [CrossRef] [PubMed]

35. Yang, L.; Zheng, Z.; Zhou, Q.; Bai, X.; Fan, L.; Yang, C.; Su, L.; Hu, D. miR-155 promotes cutaneous wound healing through enhanced keratinocytes migration by MMP-2. J. Mol. Histol. 2017, 48, 147-155. [CrossRef]

36. Vuong, T.T.; Rønning, S.B.; Ahmed, T.A.E.; Brathagen, K.; Høst, V.; Hincke, M.T.; Suso, H.P.; Pedersen, M.E. Processed eggshell membrane powder regulates cellular functions and increase MMP-activity important in early wound healing processes. PLoS ONE 2018, 13, e0201975. [CrossRef]

37. Okayama, Y. Oxidative stress in allergic and inflammatory skin diseases. Curr. Drug Targets Inflamm. Allergy 2005, 4, 517-519. [CrossRef]

38. Dunaway, S.; Odin, R.; Zhou, L.; Ji, L.; Zhang, Y.; Kadekaro, A.L. Natural Antioxidants: Multiple Mechanisms to Protect Skin From Solar Radiation. Front. Pharmacol. 2018, 9, 392. [CrossRef]

39. Cör, D.; Knez, Ž.; Knez Hrnčič, M. Antitumour, Antimicrobial, Antioxidant and Antiacetylcholinesterase Effect of Ganoderma Lucidum Terpenoids and Polysaccharides: A Review. Molecules 2018, 23, 649. [CrossRef]

40. Hu, Z.; Du, R.; Xiu, L.; Bian, Z.; Ma, C.; Sato, N.; Hattori, M.; Zhang, H.; Liang, Y.; Yu, S.; et al. Protective effect of triterpenes of Ganoderma lucidum on lipopolysaccharide-induced inflammatory responses and acute liver injury. Cytokine 2020, 127, 154917. [CrossRef]

41. Ciaglia, E.; Malfitano, A.M.; Laezza, C.; Fontana, A.; Nuzzo, G.; Cutignano, A.; Abate, M.; Pelin, M.; Sosa, S.; Bifulco, M.; et al. Immuno-Modulatory and Anti-Inflammatory Effects of Dihydrogracilin A, a Terpene Derived from the Marine Sponge Dendrilla membranosa. Int. J. Mol. Sci. 2017, 18, 1643. [CrossRef]

42. Pisanti, S.; Picardi, P.; Ciaglia, E.; Margarucci, L.; Ronca, R.; Giacomini, A.; Malfitano, A.M.; Casapullo, A.; Laezza, C.; Gazzerro, P.; et al. Antiangiogenic effects of N6-isopentenyladenosine, an endogenous isoprenoid end product, mediated by AMPK activation. FASEB J. 2014, 28, 1132-1144. [CrossRef] [PubMed]

43. Ciaglia, E.; Abate, M.; Laezza, C.; Pisanti, S.; Vitale, M.; Seneca, V.; Torelli, G.; Franceschelli, S.; Catapano, G.; Gazzerro, P.; et al. Antiglioma effects of N6-isopentenyladenosine, an endogenous isoprenoid end product, through the downregulation of epidermal growth factor receptor. Int. J. Cancer 2017, 140, 959-972. [CrossRef] [PubMed]

44. Abate, M.; Laezza, C.; Pisanti, S.; Torelli, G.; Seneca, V.; Catapano, G.; Montella, F.; Ranieri, R.; Notarnicola, M.; Gazzerro, P.; et al. Deregulated expression and activity of Farnesyl Diphosphate Synthase (FDPS) in Glioblastoma. Sci. Rep. 2017, 7, 14123. [CrossRef] [PubMed]

(C) 2020 by the authors. Licensee MDPI, Basel, Switzerland. This article is an open access article distributed under the terms and conditions of the Creative Commons Attribution (CC BY) license (http://creativecommons.org/licenses/by/4.0/). 